\title{
Entomological investigation of a sylvatic yellow fever area in São Paulo State, Brazil
}

\author{
Investigação entomológica em área \\ de ocorrência de febre amarela silvestre \\ no Estado de São Paulo, Brasil
}

Vera L. F. de Camargo-Neves 1,2 Daniela W. Poletto 1 Lílian A. C. Rodas 1 Márcio L. Pachioli 1 Rubens P. Cardoso ${ }^{1}$ Sirle A. S. Scandar 1 Susy M. P. Sampaio 1 Paulo H. Koyanagui 1 Mauricio V. Botti 1 Luis F. Mucci 1,2 Almério de C. Gomes 2

\section{Introduction}

Following reports of two autochthonous cases of sylvatic yellow fever in the State of São Paulo, Brazil, in 2000, entomological surveys were conducted with the objective of verifying the occurrence of vector species in forest environments close to or associated with riparian areas located in the western and northwestern regions of the State. Culicidae were captured in 39 sites distributed in four regions. Haemagogus leucocelaenus and Aedes albopictus were the most abundant species and were captured in all the regions studied. H. leucocelaenus was the most abundant species in the municipalities of Santa Albertina and Ouroeste, where the two cases of sylvatic yellow fever had been reported. Mosquitoes from the janthinomys/capricornii group were only found at eight sites in the São José do Rio Preto region, while Sabethes chloropterus was found at one site in Ribeirão Preto. H. leucocelaenus showed its capacity to adapt to a secondary and degraded environment. Our results indicate a wide receptive area for yellow fever transmission in the State of São Paulo, with particular emphasis on the possibility of $\mathrm{H}$. leucocelaenus being involved in the maintenance of this sylvatic focus of the disease.

Yellow Fever; Culicidae; Insect Vectors; Entomology
Mosquitoes from the Culicidae family have provided the means both for circulation of the yellow fever virus among animals and its extension to the human population. With the discovery of the occurrence of yellow fever without participation by Aedes aegypti, species from the genera Haemagogus and Sabethes were incriminated as playing a vector role between primates and humans in the sylvatic environment 1 .

In South America, epizootic events followed by cases of human infection occur according to what are still insufficiently studied cycles. Nearly two-thirds of Brazil's territory is considered an enzootic area for the virus, distributed in the North, Northeast, Central-West, Southeast, and South 2. Public health interest has been awakened by the reporting of epizootic activity in areas that were silent for several decades, as in the case of areas located in the South of the country, as well as epizootics and human cases in the Southeast 3,4 .

Enzootic activity of the yellow fever virus in municipalities (counties) infested with $A$. $a e$ gypti leads to questions concerning the probably of this virus urbanizing, supported by the oral susceptibility of $A$. aegypti samples from different regions of Brazil 5 . This possibility reopens the discussion concerning yellow fever vaccine coverage, especially in riparian areas close to urban areas infested with the vector, 
which are a priority for vaccination campaigns as a strategy to avoid introduction of the yellow fever virus into urban areas in the State of São Paulo.

Beginning in 1999, when human cases of sylvatic yellow fever were detected in the State of Goiás along with an epizootic in 54 municipalities, a shift of the virus to the South and East of Brazil was documented. The same events occurred in States such as Minas Gerais, Pará, Tocantins, Mato Grosso do Sul, and Rondônia. However, the most worrisome fact occurred in 2000, when human cases occurred outside what were considered the classical endemic areas with intact forest cover 3,6. Epizootics now occur in transformed areas and remnants of the Atlantic Forest, as in the cases reported in the States of Bahia and São Paulo 7,8.

In the State of São Paulo, sylvatic yellow fever had not been reported since 1953 , until the year 2000 when two autochthonous cases were diagnosed in the municipalities of Santa Albertina and Ouroeste 7 . These two municipalities are located in the northwestern region of the State, bordering on municipalities in the State of Minas Gerais, with the most frequent outbreaks in the Southeast of the country from 2000 to 2002. Epidemiological investigation of the two cases in São Paulo characterized the situation as one of natural foci with a high degree of deforestation and rural areas where the native vegetation was distributed in sparse remnants, sometimes as riparian forest and other times farther away from the rivers, surrounded by pasture. Degradation of the forest areas thus results from invasion by domestic animals and humans themselves.

In the epidemiological field, the region had already recorded the main vector species for sylvatic yellow fever 7 . However, studies were still lacking to monitor the effects of deforestation and alteration of the natural environment by the above-mentioned populations. Haemagogus janthinomys is known to be a sylvatic species, and it is necessary to evaluate its capacity to survive in degraded areas as well as the potential for Haemagogus leucocelaenus and other species from this genus to develop in such new environments 10. Corroborating this is the genus' long history of natural competence for yellow fever transmission in the Americas 4,11. Dégalier et al. 12 emphasized the need for research on the frequency and abundance of mosquitoes from this group in different epizootic, enzootic, and endemic areas for sylvatic yellow fever in Brazil. The present study approaches the vector issue and analyzes the distribution of species involved in the enzootic cycles of sylvatic yellow fever in secondary forests in the State of São Paulo.

\section{Material and methods}

The research areas included 39 sites belonging to 25 municipalities along the banks of the Rio Grande and Rio Paraná. These municipalities belong to the administrative regions (regional health divisions) of Ribeirão Preto, São José do Rio Preto, Araçatuba, and Presidente Prudente.

Site selection took into account the presence of secondary forest formations close to hydroelectric dams with a mean distance of $20 \mathrm{~km}$ between them, with the following sites being investigated: eight in the Ribeirão Preto region; 13 in the São José do Rio Preto region; eight in the Araçatuba region; and ten in the Presidente Prudente region, thus broadly representing the western and northwestern regions of the State of São Paulo (Figure 1).

The forest environments investigated represented riparian forests or fragments of mesophilic forests (semi-deciduous seasonal forests) in various stages of alteration, displaying both cultivated fields and pastures in adjacent areas. In the sites in the Ribeirão Preto region, the tree height varied from 8 to 20 meters, with an average of 16 meters, and fragments of forest ranged from 2.5 to 75 hectares, with a mean of 40 hectares. All the fragments were riparian forests, extending up to 50 meters away from the riverbanks. In the sites in São José do Rio Preto, the mean tree height was 12 meters, and the wooded areas ranged from 2 to 31 hectares (mean: 11 hectares). All the fragments were mesophilic forests, ten of which located less than 50 meters from the Rio Grande and three between 50 and 250 meters from the banks. In the sites located in the Araçatuba region, the trees ranged from 10 to 25 meters high, with an average of 15 meters, while the areas varied from 2 to 497 hectares (mean: 83 hectares). All the fragments were mesophilic forest and located less than 50 meters from the Rio Grande, except for one, located between 50 and 250 meters from this river. In the sites in the Presidente Prudente region, the trees ranged from 6 to 15 meters high (mean: 11 meters) and the areas ranged from 10 to 600 hectares (mean: 220 hectares). The riparian forests predominat- 


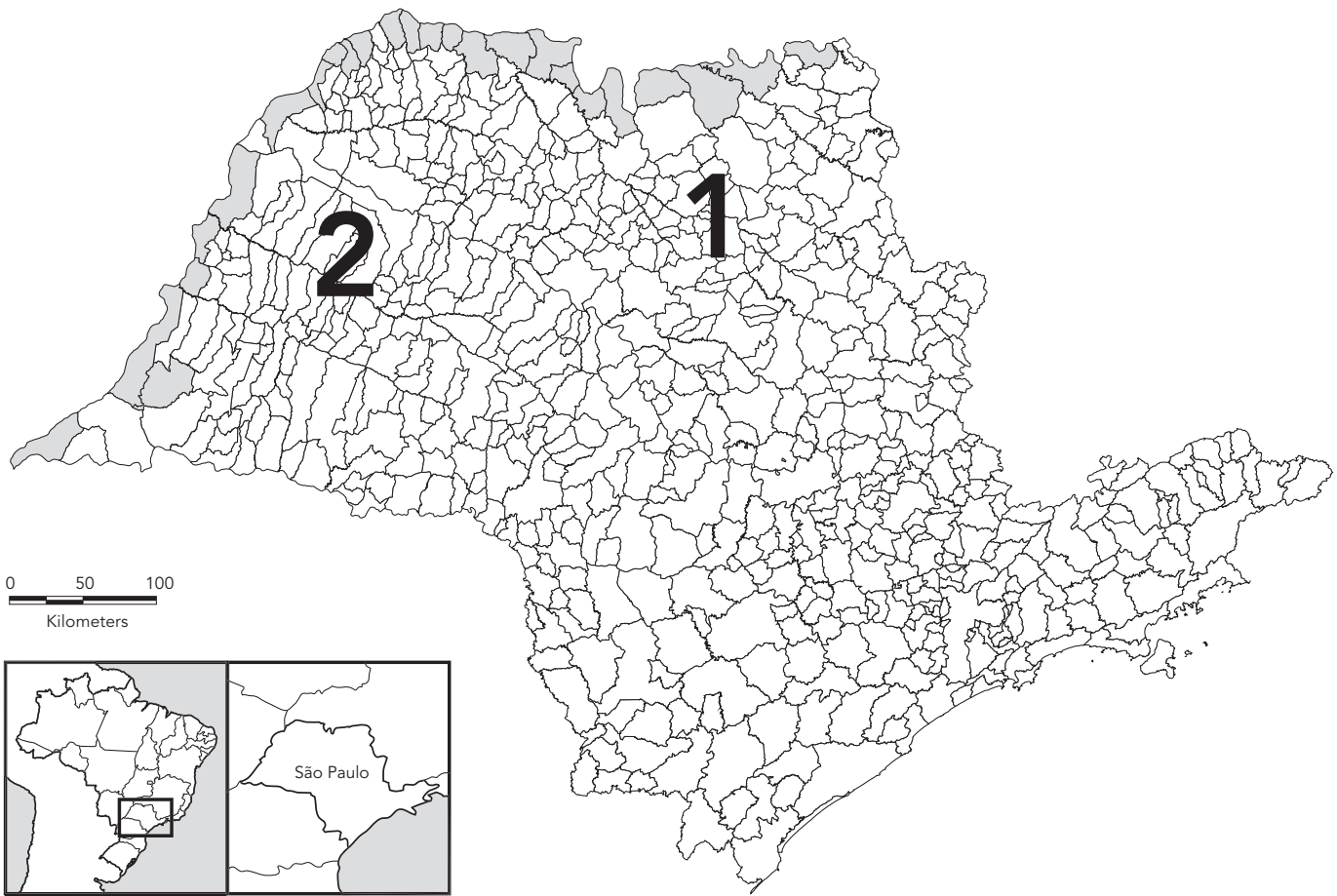

ed, five of which located within 50 meters from the river, two between 50 and 250 meters, and two between 250 and 1000 meters, with one fragment of mesophilic forest located more than one kilometer from the river.

The captures were performed quarterly over the course of one year, from July 2000 to July 2001 in São José de Rio Preto, Araçatuba, and Presidente Prudente and from July 2001 to July 2002 in Ribeirão Preto. For each site, the captures were performed on three consecutive days by a pair of technicians, one of whom crossed through the forest and the other of whom remained at a fixed point. The capture technicians switched positions every 20 minutes. The capture period was from 9:00 AM to 3:00 PM. The hand net ( $p u c ̧ a ́)$ technique was used to collect adult specimens during flight and electric aspirators or Castro traps to collect winged specimens at their landing sites.

Captured specimens were killed with chloroform vapor and stored in previously prepared entomological cases, with the time and place of capture and the technician's name recorded.
Identification of the mosquitoes used the key proposed by Consoli \& Oliveira 13 and was conducted by technicians from the Entomology Laboratories of the Regional Services in Presidente Prudente, Araçatuba, and São José do Rio Preto belonging to the Superintendency for the Control of Endemics (SUCEN). Due to the lack of morphological elements to distinguish between Haemagogus janthinomys and $\mathrm{H}$. capricornii, the two were tabulated jointly as the janthinomys/capricornii group. The result of this identification was recorded on a specific form and consolidated in a program prepared for this purpose (SUCEN, 2000).

In order to represent the abundance of genera and species, we calculated the Williams mean as proposed by Forattini 10. The data analysis used Epi Info v. 6.04.

\section{Results}

From 2000 to 2002, 39 sites were studied, resulting in the capture of 389 mosquitoes from 
genus Haemagogus (Table 1). The São José do Rio Preto region showed the greatest abundance and broadest distribution of mosquitoes from genera Sabethes and Haemagogus (Tables 1 and 2). There was an important presence of Aedes albopictus in 30 sites, including all the regions studied and particularly that of São José do Rio Preto (Table 1).

In relation to the species captured, $H$. leucocelaenus accounted for $88.4 \%, H$. janthinomys/capricornii $10.8 \%$, and Haemagogus spegazzinii $0.8 \%$ (Table 1). Specimens from the janthinomys/capricornii group, as sylvatic yellow fever vectors, were captured in eight sites, located in the regions of São José do Rio Preto (5), Araçatuba (2), and Ribeirão Preto (1); meanwhile $H$. leucocelaenus was captured in all the regions studied, with a total of 21 sites. In the Presidente Prudente region, genus Haemagogus was represented only by $H$. leucocelaenus, limited to two sites. Only 24 specimens were identified as far as genus Haemagogus, captured in eight sites in São José do Rio Preto, while for six specimens in Presidente Prudente, identification only reached genus Sabethes.

Genus Sabethes was represented by five species, of which Sabethes chloropterus (recognized as a yellow fever vector) was found only in one site in the Araçatuba region (Table 2). As for the other species from genus Sabethes, the species Sabethes glaucodaemon was found in the majority of the sites in the regions studied, except for that of Araçatuba. This species accounted for $43.1 \%$ of the sabethines captured, with a Williams mean of 14.8 specimens month/ man. S. chloropterus was captured almost exclusively in the municipality of Cardoso, while S. glaucodaemon was widely distributed in the sites in the four regions. The other species appeared only sporadically on the capture days.

Another important finding was that of 416 specimens of $A$. albopictus, sufficiently to demonstrate its wide distribution in rural areas of the State of São Paulo. The 13 municipalities in the São José do Rio Preto region were infested with this species, which totaled 146 specimens or $35.1 \%$ of all the total captures in the four regions. In the Presidente Prudente region, this mosquito corresponded to $49.5 \%$ of the specimens captured, but concentrated in the municipality of Panorama.

\section{Discussion}

The recent reporting of autochthonous human cases of sylvatic yellow fever in the northwestern and western regions of São Paulo State 50 years after the most recent previous report emphasized the need to review receptive factors that could explain the return of sylvatic transmission of this disease. The vector issue is among the factors that most prominently related to the occurrence and frequency of Haemagogus populations in relation to ecological changes that substantially affect their natural habitats. In order to address this issue, the current study evaluated elements related to vector capacity.

Different horizontal and vertical dimensions in the forest fragments were studied based on the hypothesis that sylvatic yellow fever vectors might be responding differently to deforestation and ecological instability in the forest remnants. The wooded areas in São José do Rio Preto, which were smaller and had more open tree crowns and a predominant height of 12 meters, and the fragments in Ribeirão Preto and Araçatuba, with maximum heights of 25 meters, showed differential results in the presence and abundance of Haemagogus and $S a$ bethes mosquitoes.

Sabethines were the most frequently captured mosquitoes, especially $S$. glaucodaemon (Table 2). Despite the supposed involvement of this group in the enzootic maintenance of the yellow fever virus, these are the least studied species in this regard. S. chloropterus, considered an important vector for sylvatic yellow fever, occurred with low abundance $\left(\mathrm{X}_{\mathrm{W}}=0.096\right)$ and in only one site, in the Araçatuba region, where the forest was more preserved as compared to the other areas studied (Table 2), thus appearing not to explain the transmission of the yellow fever virus to humans. In fact, this finding did not coincide with the municipalities where the two cases were reported. This low abundance and the absence of this species in the other areas suggest its lack of adaptation to secondary forests, and although the captures were conducted at the ground level, the species may also have been affected in terms of its acrodendrophilic habits 14,15.

In the São José do Rio Preto region, the janthinomys/capricornii group was found in five out of eight sites studied, including those where there was human transmission of sylvatic yellow fever. The group's reduced presence, with a density ranging from 0.03 to 0.24 (Table 1 ), suggests a response by the group to different degrees of alterations in the habitats. Note that Forattini 16 reported the occurrence of $H$. capricornii in domain cerrado (savannah) areas in the State of São Paulo, which supports the suspicion that this species is occurring in this region. Concerning its abundance, our re- 
Table 1

Frequency of mosquitoes from the genera Haemagogus and Aedes albopictus by site, municipality, and administrative region in the State of São Paulo, Brazil, 2000/2002.

\begin{tabular}{|c|c|c|c|c|c|c|c|c|c|c|c|}
\hline \multirow[t]{3}{*}{ Municipality } & \multirow[t]{3}{*}{ Site } & \multicolumn{10}{|c|}{ Species } \\
\hline & & \multicolumn{2}{|c|}{$\begin{array}{l}\text { H. janthynomis } \\
\text { /capricornii }\end{array}$} & \multicolumn{2}{|c|}{ H. leucocelaenus } & \multicolumn{2}{|c|}{ H. spegazzinii } & \multicolumn{2}{|c|}{$\begin{array}{c}\text { Total from genus } \\
\text { Haemagogus }\end{array}$} & \multicolumn{2}{|c|}{ Aedes albopictus } \\
\hline & & $n$ & $X_{w}$ & $\mathrm{n}$ & $X_{w}$ & $n$ & $X w$ & $\mathrm{n}$ & $X_{w}$ & $\mathrm{n}$ & $X w$ \\
\hline Ribeirão Preto region & & 3 & 0.08 & 2 & 0.07 & 1 & 0.03 & 6 & 0.18 & 20 & 0.76 \\
\hline Igarapava & 1 & 0 & 0.00 & 0 & 0.00 & 0 & 0.00 & 0 & 0.00 & 7 & 0.31 \\
\hline \multirow[t]{3}{*}{ Miguelópolis } & 2 & 0 & 0.00 & 0 & 0.00 & 0 & 0.00 & 0 & 0.00 & 0 & 0.00 \\
\hline & 3 & 0 & 0.00 & 0 & 0.00 & 0 & 0.00 & 0 & 0.00 & 2 & 0.08 \\
\hline & 4 & 0 & 0.00 & 1 & 0.03 & 0 & 0.00 & 1 & 0.03 & 3 & 0.14 \\
\hline Guaíra & 5 & 0 & 0.00 & 0 & 0.00 & 0 & 0.00 & 0 & 0.00 & 0 & 0.00 \\
\hline \multirow[t]{2}{*}{ Colombia } & 6 & 0 & 0.00 & 1 & 0.03 & 0 & 0.00 & 1 & 0.03 & 0 & 0.00 \\
\hline & 7 & 3 & 0.08 & 0 & 0.00 & 0 & 0.00 & 3 & 0.08 & 0 & 0.00 \\
\hline Guaraci & 8 & 0 & 0.00 & 0 & 0.00 & 1 & 0.03 & 1 & 0.03 & 8 & 0.26 \\
\hline São José do Rio Preto region & & 39 & 0.84 & 324 & 3.71 & 2 & 0.07 & 365 & 4.33 & 146 & 5.89 \\
\hline Icem & 9 & 0 & 0.00 & 7 & 0.20 & 0 & 0.00 & 7 & 0.20 & 36 & 1.13 \\
\hline Orindiúva & 10 & 1 & 0.10 & 67 & 0.80 & 0 & 0.00 & 68 & 0.83 & 4 & 0.65 \\
\hline Paulo de Faria & 11 & 0 & 0.00 & 54 & 0.64 & 0 & 0.00 & 54 & 0.64 & 23 & 0.91 \\
\hline Riolândia & 12 & 14 & 0.25 & 52 & 0.54 & 1 & 0.03 & 67 & 0.72 & 3 & 0.12 \\
\hline Cardoso & 13 & 0 & 0.00 & 16 & 0.24 & 0 & 0.00 & 16 & 0.24 & 3 & 0.11 \\
\hline Mira Estrela & 14 & 11 & 0.24 & 3 & 0.10 & 0 & 0.00 & 14 & 0.33 & 1 & 0.04 \\
\hline Indiaporã & 15 & 0 & 0.00 & 3 & 0.10 & 0 & 0.00 & 3 & 0.10 & 20 & 0.68 \\
\hline Ouroeste & 16 & 3 & 0.10 & 27 & 0.41 & 0 & 0.00 & 30 & 0.45 & 2 & 0.11 \\
\hline Populina & 17 & 0 & 0.00 & 2 & 0.06 & 0 & 0.00 & 2 & 0.06 & 3 & 0.12 \\
\hline Santa Albertina & 18 & 0 & 0.00 & 89 & 0.50 & 0 & 0.00 & 89 & 0.50 & 4 & 0.18 \\
\hline Santa Rita d'Oeste & 19 & 10 & 0.16 & 1 & 0.03 & 1 & 0.03 & 12 & 0.18 & 14 & 0.58 \\
\hline Santa Clara d'Oeste & 20 & 0 & 0.00 & 0 & 0.00 & 0 & 0.00 & 0 & 0.00 & 28 & 1.07 \\
\hline Rubinéia & 21 & 0 & 0.00 & 3 & 0.10 & 0 & 0.00 & 3 & 0.10 & 5 & 0.20 \\
\hline Araçatuba region & & 3 & 0.09 & 14 & 0.41 & 0 & 0.00 & 17 & 0.51 & 44 & 1.84 \\
\hline \multirow[t]{5}{*}{ Ilha Solteira } & 22 & 0 & 0.00 & 4 & 0.12 & 0 & 0.00 & 4 & 0.12 & 19 & 0.75 \\
\hline & 23 & 0 & 0.00 & 1 & 0.03 & 0 & 0.00 & 1 & 0.03 & 6 & 0.29 \\
\hline & 24 & 0 & 0.00 & 4 & 0.10 & 0 & 0.00 & 4 & 0.10 & 2 & 0.07 \\
\hline & 25 & 0 & 0.00 & 1 & 0.03 & 0 & 0.00 & 1 & 0.03 & 0 & 0.00 \\
\hline & 26 & 0 & 0.00 & 0 & 0.00 & 0 & 0.00 & 0 & 0.00 & 2 & 0.07 \\
\hline \multirow[t]{3}{*}{ Castilho } & 27 & 1 & 0.03 & 4 & 0.12 & 0 & 0.00 & 5 & 0.16 & 10 & 0.47 \\
\hline & 28 & 2 & 0.06 & 0 & 0.00 & 0 & 0.00 & 2 & 0.06 & 0 & 0.00 \\
\hline & 29 & 0 & 0.00 & 0 & 0.00 & 0 & 0.00 & 0 & 0.00 & 5 & 0.19 \\
\hline Presidente Prudente region & & 0 & 0.00 & 4 & 0.12 & 0 & 0.00 & 4 & 0.12 & 206 & 2.23 \\
\hline Paulicéia & 30 & 0 & 0.00 & 2 & 0.06 & 0 & 0.00 & 2 & 0.06 & 3 & 0.12 \\
\hline Panorama & 31 & 0 & 0.00 & 2 & 0.06 & 0 & 0.00 & 2 & 0.06 & 192 & 1.73 \\
\hline \multirow[t]{2}{*}{ Presidente Epitácio } & 32 & 0 & 0.00 & 0 & 0.00 & 0 & 0.00 & 0 & 0.00 & 0 & 0.00 \\
\hline & 33 & 0 & 0.00 & 0 & 0.00 & 0 & 0.00 & 0 & 0.00 & 6 & 0.19 \\
\hline Marabá Paulista & 34 & 0 & 0.00 & 0 & 0.00 & 0 & 0.00 & 0 & 0.00 & 1 & 0.04 \\
\hline \multirow[t]{5}{*}{ Rosana } & 35 & 0 & 0.00 & 0 & 0.00 & 0 & 0.00 & 0 & 0.00 & 1 & 0.04 \\
\hline & 36 & 0 & 0.00 & 0 & 0.00 & 0 & 0.00 & 0 & 0.00 & 2 & 0.07 \\
\hline & 37 & 0 & 0.00 & 0 & 0.00 & 0 & 0.00 & 0 & 0.00 & 0 & 0.00 \\
\hline & 38 & 0 & 0.00 & 0 & 0.00 & 0 & 0.00 & 0 & 0.00 & 0 & 0.00 \\
\hline & 39 & 0 & 0.00 & 0 & 0.00 & 0 & 0.00 & 0 & 0.00 & 1 & 0.04 \\
\hline Total & & 42 & 1.01 & 344 & 4.31 & 3 & 0.10 & 389 & 5.14 & 416 & 10.74 \\
\hline
\end{tabular}


Frequency of mosquitoes from genus Sabethes by site, municipality, and administrative region in the State of São Paulo. Brazil, $2000 / 2002$.

\begin{tabular}{|c|c|c|c|c|c|c|c|c|c|c|c|c|c|}
\hline \multirow[t]{3}{*}{ Municipality } & \multirow[t]{3}{*}{ Site } & \multicolumn{12}{|c|}{ Species } \\
\hline & & \multicolumn{2}{|c|}{ S. chloropterus } & \multicolumn{2}{|c|}{ S. glaucodaemon } & \multicolumn{2}{|c|}{ S. albipprivus } & \multicolumn{2}{|c|}{ S. tarsopus } & \multicolumn{2}{|c|}{ S. tridentatus } & \multicolumn{2}{|c|}{$\begin{array}{c}\text { Total from genus } \\
\text { Sabethes }\end{array}$} \\
\hline & & $n$ & $X_{w}$ & $\mathrm{n}$ & $X_{w}$ & $\mathrm{n}$ & $X_{w}$ & $\mathrm{n}$ & $X_{w}$ & $\mathrm{n}$ & $X_{w}$ & $\mathrm{n}$ & $X_{w}$ \\
\hline Ribeirão Preto region & & 0 & 0.00 & 101 & 2.34 & 0 & 0.00 & 0 & 0.00 & 0 & 0.00 & 101 & 2.34 \\
\hline Igarapava & 1 & 0 & 0.00 & 25 & 0.54 & 0 & 0.00 & 0 & 0.00 & 0 & 0.00 & 25 & 0.54 \\
\hline \multirow[t]{3}{*}{ Miguelópolis } & 2 & 0 & 0.00 & 10 & 0.24 & 0 & 0.00 & 0 & 0.00 & 0 & 0.00 & 10 & 0.24 \\
\hline & 3 & 0 & 0.00 & 18 & 0.38 & 0 & 0.00 & 0 & 0.00 & 0 & 0.00 & 18 & 0.38 \\
\hline & 4 & 0 & 0.00 & 15 & 0.37 & 0 & 0.00 & 0 & 0.00 & 0 & 0.00 & 15 & 0.37 \\
\hline Guaíra & 5 & 0 & 0.00 & 7 & 0.21 & 0 & 0.00 & 0 & 0.00 & 0 & 0.00 & 7 & 0.21 \\
\hline \multirow[t]{2}{*}{ Colombia } & 6 & 0 & 0.00 & 11 & 0.25 & 0 & 0.00 & 0 & 0.00 & 0 & 0.00 & 11 & 0.25 \\
\hline & 7 & 0 & 0.00 & 15 & 0.35 & 0 & 0.00 & 0 & 0.00 & 0 & 0.00 & 15 & 0.35 \\
\hline Guaraci & 8 & 0 & 0.00 & 0 & 0.00 & 0 & 0.00 & 0 & 0.00 & 0 & 0.00 & 0 & 0.00 \\
\hline \multicolumn{14}{|l|}{ Rio Preto region } \\
\hline Icem & 9 & 0 & 0.00 & 31 & 0.55 & 0 & 0.00 & 0 & 0.00 & 1 & 0.03 & 32 & 0.56 \\
\hline Orindiúva & 10 & 0 & 0.00 & 38 & 0.81 & 0 & 0.00 & 1 & 0.03 & 1 & 0.07 & 40 & 0.83 \\
\hline Paulo de Faria & 11 & 0 & 0.00 & 20 & 0.48 & 0 & 0.00 & 0 & 0.00 & 1 & 0.03 & 21 & 0.51 \\
\hline Riolândia & 12 & 0 & 0.00 & 9 & 0.24 & 0 & 0.00 & 0 & 0.00 & 0 & 0.00 & 9 & 0.24 \\
\hline Cardoso & 13 & 0 & 0.00 & 37 & 0.73 & 0 & 0.00 & 1.108 & 2.83 & 4 & 0.13 & 1.149 & 3.20 \\
\hline Mira Estrela & 14 & 0 & 0.00 & 29 & 0.62 & 0 & 0.00 & 0 & 0.00 & 0 & 0.00 & 29 & 0.62 \\
\hline Indiaporã & 15 & 0 & 0.00 & 32 & 0.60 & 0 & 0.00 & 0 & 0.00 & 4 & 0.10 & 36 & 0.66 \\
\hline Ouroeste & 16 & 0 & 0.00 & 79 & 0.99 & 0 & 0.00 & 1 & 0.03 & 0 & 0.00 & 80 & 0.99 \\
\hline Populina & 17 & 0 & 0.00 & 65 & 0.81 & 0 & 0.00 & 0 & 0.00 & 0 & 0.00 & 65 & 0.81 \\
\hline Santa Albertina & 18 & 0 & 0.00 & 140 & 1.23 & 0 & 0.00 & 0 & 0.00 & 1 & 0.03 & 141 & 1.24 \\
\hline Santa Rita d'Oeste & 19 & 0 & 0.00 & 169 & 1.42 & 0 & 0.00 & 0 & 0.00 & 3 & 0.08 & 172 & 1.43 \\
\hline Santa Clara d'Oeste & 20 & 0 & 0.00 & 29 & 0.46 & 0 & 0.00 & 1 & 0.03 & 3 & 0.10 & 33 & 0.50 \\
\hline Rubinéia & 21 & 0 & 0.00 & 106 & 10.26 & 0 & 0.00 & 0 & 0.00 & 2 & 0.06 & 108 & 1.32 \\
\hline Araçatuba region & & 4 & 0.10 & 0 & 0.00 & 3 & 0.08 & 0 & 0.00 & 1 & 0.03 & 8 & 0.21 \\
\hline \multirow[t]{5}{*}{ Ilha Solteira } & 22 & 4 & 0.10 & 0 & 0.00 & 0 & 0.00 & 0 & 0.00 & 0 & 0.00 & 4 & 0.10 \\
\hline & 23 & 0 & 0.00 & 0 & 0.00 & 0 & 0.00 & 0 & 0.00 & 1 & 0.03 & 1 & 0.03 \\
\hline & 24 & 0 & 0.00 & 0 & 0.00 & 0 & 0.00 & 0 & 0.00 & 0 & 0.00 & 0 & 0.00 \\
\hline & 25 & 0 & 0.00 & 0 & 0.00 & 0 & 0.00 & 0 & 0.00 & 0 & 0.00 & 0 & 0.00 \\
\hline & 26 & 0 & 0.00 & 0 & 0.00 & 0 & 0.00 & 0 & 0.00 & 0 & 0.00 & 0 & 0.00 \\
\hline \multirow[t]{3}{*}{ Castilho } & 27 & 0 & 0.00 & 0 & 0.00 & 3 & 0.08 & 0 & 0.00 & 0 & 0.00 & 3 & 0.08 \\
\hline & 28 & 0 & 0.00 & 0 & 0.00 & 0 & 0.00 & 0 & 0.00 & 0 & 0.00 & 0 & 0.00 \\
\hline & 29 & 0 & 0.00 & 0 & 0.00 & 0 & 0.00 & 0 & 0.00 & 0 & 0.00 & 0 & 0.00 \\
\hline $\begin{array}{l}\text { Presidente Prudente } \\
\text { region }\end{array}$ & & 0 & 0.00 & 130 & 2.25 & 178 & 2.95 & 0 & 0.00 & 24 & 0.29 & 332 & 4.82 \\
\hline Paulicéia & 30 & 0 & 0.00 & 7 & 0.18 & 0 & 0.00 & 0 & 0.00 & 0 & 0.00 & 7 & 0.18 \\
\hline Panorama & 31 & 0 & 0.00 & 28 & 0.41 & 46 & 0.84 & 0 & 0.00 & 2 & 0.06 & 76 & 1.11 \\
\hline \multirow[t]{2}{*}{ Presidente Epitácio } & 32 & 0 & 0.00 & 1 & 0.03 & 9 & 0.15 & 0 & 0.00 & 0 & 0.00 & 10 & 0.16 \\
\hline & 33 & 0 & 0.00 & 16 & 0.30 & 0 & 0.00 & 0 & 0.00 & 0 & 0.00 & 16 & 0.30 \\
\hline Marabá Paulista & 34 & 0 & 0.00 & 50 & 0.63 & 32 & 0.62 & 0 & 0.00 & 0 & 0.00 & 82 & 0.99 \\
\hline \multirow[t]{5}{*}{ Rosana } & 35 & 0 & 0.00 & 0 & 0.00 & 6 & 0.12 & 0 & 0.00 & 0 & 0.00 & 6 & 0.12 \\
\hline & 36 & 0 & 0.00 & 6 & 0.18 & 84 & 1.18 & 0 & 0.00 & 0 & 0.00 & 90 & 1.24 \\
\hline & 37 & 0 & 0.00 & 11 & 0.24 & 0 & 0.00 & 0 & 0.00 & 0 & 0.00 & 11 & 0.24 \\
\hline & 38 & 0 & 0.00 & 8 & 0.17 & 1 & 0.03 & 0 & 0.00 & 0 & 0.00 & 9 & 0.20 \\
\hline & 39 & 0 & 0.00 & 3 & 0.10 & 0 & 0.00 & 0 & 0.00 & 22 & 0.23 & 25 & 0.28 \\
\hline Total & & 4 & 0.10 & 1.900 & 14.84 & 184 & 3.03 & 2.221 & 2.93 & 64 & 0.96 & 4.373 & 20.29 \\
\hline
\end{tabular}


sults were similar to findings in Bolivia 17, where $H$. janthinomys was found in low deciduous gallery forests with penetration of sunlight. Fé et al. 18, studying five rural areas in municipalities in the State of Amazonas, found H. janthinomys in only two areas and with few specimens. However, despite the low abundance in the areas studied, this species merits attention due to the fact that it has been found under natural conditions with the yellow fever virus and conducting a vertical transmission cycle 19 . In addition, its vector role is emphasized more by its anthropophilic nature than by its abundance 20,21.

Considering the levels of environmental alterations and the remnants of native forest, the data suggest greater capacity by $H$. leucocelaenus to survive the environmental transition phase, as observed in the area studied. This species was found in all the administrative regions that were studied, representing $53.9 \%$ of the sites (21/39), with particular emphasis on its presence in the São José do Rio Preto region, that is, in twelve of the thirteen sites with a median abundance ranging from 0.03 to 0.80 (Table 1). It was the most abundant species in the municipalities of Ouroeste $\left(X_{W}=0.41\right)$ and Santa Albertina $\left(X_{W}=0.50\right)$, where the cases of sylvatic yellow fever were reported. In addition, it showed higher frequency as compared to the other species from genus Haemagogus. As in the State of São Paulo, reports from the State of Rio Grande do Sul 4 have shown that this species is present in small semi-deciduous forest areas with low tree height surrounded naturally by clearings. H. leucocelaenus has a long history of vector competence, having participated in various yellow fever epizootics, which corroborates the hypothesis of its possible involvement in transmission of the sylvatic virus in the State of São Paulo 1,4,11,20. The report of H. leucocelaenus in a yellow fever transmission area in Bolivia 17, located in more open gallery forests, reaffirms that its proliferation occurs in degraded environments and those where humans circulate. All these reports indicate that this species may potentially predominate in forests with various degrees of degradation. In northwestern and western São Paulo State, H. leuco- celaenus proved to be more capable of occupying the niches created by the degradation of natural environments and may thus indicate a significant potential for the species' adaptability. Under these circumstances and in some locations, this species could play an important vector role.

The wide distribution of A. albopictus in the regions studied, with a high abundance in various locations in all the regions, including an overlap with the epizootic yellow fever area, poses the possibility of contact between this mosquito and the yellow fever virus in its natural cycle, allowing transfer of the sylvatic agent to periurban and urban areas. In studies on the infectivity of $A$. albopictus in various Brazilian regions, Lourenço-de-Oliviera et al. 22 showed that in laboratory this species presented high yellow fever virus infection rates. Confirmation of its vector competence, added to its capacity for dispersion and higher densities in transition areas for sylvatic yellow fever, combine to recommend further studies to evaluate the vector role of A. albopictus in order to subsequently measure the odds of transferring the yellow fever virus to urban areas. This is corroborated by reports by Chiaravalloti et al. 7 in São José do Rio Preto and Gomes et al. 23 in Bataguassu, Mato Grosso do Sul.

Finally, it appears evident that the ecological succession resulting from changes in the forest environment has favored $H$. leucocelaenus. Thus, the maintenance of natural yellow fever foci in the region includes participation by this species and the janthinomys/capricornii group, especially in the São José do Rio Preto region. Consequently, these species are suspected of being involved in the transmission of the two recent cases of sylvatic yellow fever. In addition, the epizootics recorded in the South of Brazil, with isolation of the virus in H. leucocelaenus 4 , supports the reasoning that such epizootics reflect these changes in the disease's ecology. Furthermore, the results of the current study allow expanding the classification of risk areas for yellow fever transmission in the State of São Paulo and should also be useful for defining a more adequate strategy to protect the resident communities in these areas. 
Resumo

O registro de dois casos autóctones de febre amarela silvestre no Estado de São Paulo, Brasil, em 2000, desencadeou investigações entomológicas com o objetivo de verificar a ocorrência das espécies vetoras em ambientes florestais próximos ou associados às zonas ribeirinhas, situados nas regiões oeste e noroeste do Estado. As capturas foram realizadas em 39 localidades distribuídas por quatro regiões do Estado. Haemagogus leucocelaenus $e$ Aedes albopictus foram as espécies mais abundantes e capturadas em todas as regiões. H. leucocelaenus foi a espécie mais abundante nos municípios de Santa Albertina e Ouroeste, onde os casos de febre amarela silvestre foram registrados. Mosquitos do grupo janthinomys/capricornii foram encontrados em oito localidades de São José do Rio Preto, enquanto Sabethes chloropterus uma única vez em localidade de Ribeirão Preto. Ficou evidenciada a aptidão de $\mathrm{H}$. leucocelaenus para adaptar-se a ambiente secundário e degradado. Nossos resultados apontam para uma ampla área receptiva para a transmissão de febre amarela, com destaque para a possibilidade de $\mathrm{H}$. leucocelaenus estar envolvido na manutenção deste foco silvestre da doença.

Febre Amarela; Culicidae; Insetos Vetores; Entomologia

\section{Collaborators}

V. L. F. de Camargo-Neves participated in all the stages of the study, including its original conceptualization, design, overall coordination, interpretation and analysis of the results, and final drafting of the article. D. W. Poletto, L. A. C. Rodas, and M. L. Pachioli participated in the design and were responsible for the entomological captures in the Araçatuba region, identification of the insects from Araçatuba and Ribeirão Preto, and data compilation from the region. R. P. Cardoso and S. A. S. Scandar participated in the design and were responsible for the entomological captures in the São José do Rio Preto region, identification of the insects, and data compilation from the region. S. M. P. Sampaio and P. H. Koyanagui participated in the design and were responsible for the entomological captures in the Presidente Prudente region, identification of the insects, and data compilation from the region. M. V. Botti coordinated the captures in Ribeirão Preto. L. F. Mucci was responsible for combining the databases, and interpretation and discussion of the results. A. C. Gomes participated in the design, interpretation, and discussion of the results and drafting and final revision of the article.

\section{References}

1. Soper FL, Penna HA, Cardoso E, Serafin Jr. J, Frobisher Jr. M, Pinheiro J. Yellow fever without Aedes aegypti. Study of a rural epidemic in the Valle do Chanaan, Espírito Santo, Brazil, 1932. Am J Hyg 1933; 18:555-87.

2. Vasconcelos PFC, Rodrigues SG, Degallier N, Moraes MA, Travassos-da-Rosa JFS, Travassos-daRosa ES, et al. An epidemic of sylvatic yellow fever in the southeast region of Maranhão State, Brazil, 1993-1994: epidemiologic and entomologic findings. Am J Trop Med Hyg 1997; 57:132-7.

3. Carmo EH, Martins E, Pelucci H, Maia ML, Duzzi $\mathrm{R}$, Tubois S, et al. Brote de fiebre amarilla selvática en Minas Gerais, Brasil. Boletín Informativo PAI, Programa Ampliado de Inmunización en las Américas 2002; XXIV:5-6.

4. Vasconcelos PFC, Sperb AF, Monteiro HAO, Torres MAN, Sousa MRS, Vasconcelos HB, et al. Isolations of yellow fever virus from Haemagogus leucocelaenus in Rio Grande do Sul State, Brazil. Trans R SocTrop Med Hyg 2003; 97:60-2.

5. Lourenço-de-Oliveira R, Vazeille M, Filippis AMB, Failloux AB. Oral susceptibility to yellow virus of Aedes aegypti from Brazil. Mem Inst Oswaldo Cruz 2002; 97:437-9.

6. Fundação Nacional de Saúde. Dados sobre febre amarela silvestre 2001. http:/ / www.funasa.gov. br/epi/fa/pdfs/mapa_brasil_fa.gif (acessado em 08/Mar/2003).

7. Chiaravalloti Neto F, Dibo MR, Barbosa AAC, Battigaglia M. Aedes albopictus na região de São José do Rio Preto, SP: estudo da sua infestação em área já ocupada pelo Aedes aegypti e discussão de seu papel como possível vetor de dengue e febre amarela. Rev Soc Bras Med Trop 2002; 35:351-7.

8. Vasconcelos PFC, Costa ZG, Travassos-da-Rosa ES, Luna E, Rodrigues SG, Barros VLRS, et al. Epidemic of jungle yellow fever in Brazil, 2000: implications of climatic alterations in disease spread. J Med Virol 2001; 65:598-604.

9. Coimbra TLM, Iverson LB, Spir M, Alves VAF, Boulos M. Investigação epidemiológica de casos de febre amarela na região Noroeste do Estado de São Paulo, Brasil. Rev Saúde Pública 1987; 21:191-9.

10. Forattini OP. Culicidologia médica. v. 2. São Paulo: Edusp; 2002.

11. Kumm HW, Cerqueira NL. The role of Aedes leucocelaenus in the epidemiology of jungle yellow fever in Brazil. Bull Entomol Research 1951; 42:195200.

12. Dégallier N, Rosa APAT, Vasconcelos PFC, Rosa EST, Rodrigues SG, Sá Filho GC, et al. New entomological and virological data on the vectors of sylvatic yellow fever in Brazil. J Brazilian Assoc Advanc Sci 1992; 44:136-42.

13. Consoli RAGB, Oliveira RL. Principais mosquitos de importância sanitária no Brasil. Rio de Janeiro: Editora Fiocruz; 1994.

14. Dégallier N, Rosa APAT, Vasconcelos PFC, Hervé JP, Sá Filho GC, Rosa JFS, et al. Modifications of arbovirus transmission in relation to construction of dams in Brazilian Amazonia. J Brazilian Assoc Advanc Sci 1992; 44:124-35. 
15. Chadee DD. Seasonal abundance and diel landing periodicity of Sabethes chloropterus (Diptera: Culicidae) in Trinidad, West Indies. J Med Entomol 1990; 27:1041-4.

16. Forattini OP. Entomologia médica. v. 2. São Paulo: Edusp; 1965.

17. Roberts DR, Peyton EL, Pinheiro FP, Balderrama F, Vargas R. Associations of arbovirus vectors with gallery forest and domestic environments in southeastern Bolivia. PAHO Bull 1984; 18:337-50.

18. Fé NF, Barbosa MGV, Fé FAA, Guerra MVF, Alecrim WD. Fauna Culicidae em municípios da zona rural do Estado do Amazonas, com incidência de febre amarela. Rev Soc Bras Med Trop 2003; 36: 343-8.

19. Mondet B, Vasconcelos PFC, Travassos-da-Rosa APA, Travassos-da-Rosa ES, Rodrigues SG, Travassos-da-Rosa JFS, et al. Isolation of yellow fever virus from nulliparous Haemagogus (Haemagogus) janthinomys in Eastern Amazonia. Vector Borne Zoo Dis 2002; 2:47-50.
20. Hervé JP, Travassos-da-Rosa APA. Ecologia da febre amarela no Brasil. Fundação SESP 1983; 28: 11-9.

21. Chadee DD, Tikasing ES, Ganesh R. Seasonality, biting cycle and parity of the yellow fever vector mosquito Haemagogus janthinomys in Trinidad. Med Vet Entomol 1992; 6:143-8.

22. Lourenço-de-Oliveira R, Vazeille M, Filippis AMB, Failloux AB. Large genetic differentiation and low variation in vector competence for dengue and yellow fever viruses of Aedes albopictus from Brazil, The United States and The Cayman Islands. Am J Trop Med Hyg 2003; 69:105-14.

23. Gomes AC, Bitencourt MD, Natal D, Pinto PLS, Mucci LF, Paula MB, et al. Aedes albopictus em área rural do Brasil e implicações na transmissão de febre amarela silvestre. Rev Saúde Pública 1999; 33:95-7.

Submitted on 13/May/2004

Final version resubmitted on 31/Aug/2004

Approved on 07/Oct/2004 